University of Nebraska - Lincoln

DigitalCommons@University of Nebraska - Lincoln

USDA National Wildlife Research Center - Staff Publications
U.S. Department of Agriculture: Animal and Plant Health Inspection Service

$11-15-2002$

\title{
A Socioeconomic and Biological Evaluation of Current and Hypothetical Crappie Regulations in Sardis Lake, Mississippi: An Integrated Approach
}

\author{
Brian Dorr \\ Mississippi Cooperative Fish and Wildlife Research Unit, brian.s.dorr@aphis.usda.gov \\ Ian A. Munn \\ Mississippi State University \\ Keith O. Meals \\ Mississippi Department of Wildlife, Fisheries, and Parks
}

Follow this and additional works at: https://digitalcommons.unl.edu/icwdm_usdanwrc

Part of the Environmental Sciences Commons

Dorr, Brian; Munn, lan A.; and Meals, Keith O., "A Socioeconomic and Biological Evaluation of Current and Hypothetical Crappie Regulations in Sardis Lake, Mississippi: An Integrated Approach" (2002). USDA National Wildlife Research Center - Staff Publications. 478.

https://digitalcommons.unl.edu/icwdm_usdanwrc/478

This Article is brought to you for free and open access by the U.S. Department of Agriculture: Animal and Plant Health Inspection Service at DigitalCommons@University of Nebraska - Lincoln. It has been accepted for inclusion in USDA National Wildlife Research Center - Staff Publications by an authorized administrator of DigitalCommons@University of Nebraska - Lincoln. 


\title{
A Socioeconomic and Biological Evaluation of Current and Hypothetical Crappie Regulations in Sardis Lake, Mississippi: An Integrated Approach
}

\author{
BRIAN DORR*1 \\ Mississippi Cooperative Fish and Wildlife Research Unit, \\ Post Office Box 9691, \\ Mississippi State, Mississippi 39762, USA \\ IAn A. MunN \\ Mississippi State University, Forestry Department, \\ Thompson Hall, Room 349, \\ Mississippi State, Mississippi 39762, USA \\ Keith O. Meals \\ Mississippi Department of Wildlife, Fisheries, and Parks, \\ District Two Office, 253 Eureka Street, \\ Batesville, Mississippi 38605, USA
}

\begin{abstract}
We conducted a socioeconomic survey and review of existing biological data in an integrated evaluation of current and hypothetical fishery regulations on crappies Pomoxis spp. in Sardis Lake, Mississippi. The objectives of this study were to (1) assess angler acceptance of current and hypothetical harvest restrictions, (2) determine the recreational value of the crappie fishery to its participants, (3) estimate possible changes in recreational value based on angler responses to hypothetical regulations, and (4) integrate the results of the socioeconomic surveys with existing biological information. Using the travel cost method, we estimated mean expenditures at US\$29.48 and average consumer surplus per angler per trip at $\$ 8.88$. We estimated 75,601 crappie angler trips in 1995, yielding an annual consumer surplus for the Sardis Lake crappie fishery of $\$ 671,000$ and a gross willingness to pay (GWP) of $\$ 2.9$ million. Hypothetical changes in creel limits would have greater effects on the crappie fishery than would changes in length limits. If a creel limit of 10 crappies/d were implemented, 24,986 fewer angler trips could be expected, reducing both consumer surplus and GWP approximately 33\% (\$222,000 and $\$ 958,000$, respectively). Changes in angler trips related to length limits were small $(<4 \%)$ until a $31-\mathrm{cm}$ length limit was proposed, for which 7,035 fewer angler trips could be expected, reducing consumer surplus and GWP approximately $9 \%$ each (\$61,900 and \$270,000, respectively). Biological evaluations of the effects of length and creel limits suggested they are unlikely to affect crappie populations unless they are much more restrictive than current regulations. Combined, biological and socioeconomic information supported continuing the current 25.4-cm length limit and 30-fish/d creel limit.
\end{abstract}

Freshwater fisheries are an important renewable resource. Resident and nonresident anglers spent 9.732 million angler-days and US\$703.692 million in Mississippi in 1996 (USFWS 1996). Despite the importance of fisheries to regional, state, and local economies, regulatory decisions often are made with little information on the possible socioeco-

\footnotetext{
* Corresponding author: brian.s.dorr@usda.gov

${ }^{1}$ Present address: U.S. Department of Agriculture, Animal and Plant Health Inspection Service, Wildlife Services, National Wildlife Research Center, Post Office Drawer 6099, Mississippi State, Mississippi 397626099, USA.
}

Received December 1, 2000; accepted April 29, 2002 nomic effects of regulations. Because people are the ultimate beneficiaries of fisheries management, fisheries professionals should consider the social and economic effects of their management efforts (Weithman 1993). Knowledge of the socioeconomic effects of various harvest restrictions will allow fishery managers to develop and evaluate regulations that address the needs of the fishery.

Valuation of natural resources is necessary to substantiate management actions and allocation decisions (Weithman 1993). An estimate of the recreational value of a fishery is necessary in evaluating potential effects of harvest restrictions on a fishery and enables evaluation of the interactions between changes in harvest restrictions and the value placed on the fishery. 
Biological and socioeconomic data can be combined to develop fishery management plans that address the goals and viewpoints of anglers and fishery managers (Prochaska and Cato 1983). Harvest restrictions may meet goals of maintaining the biological health of a fish population yet may be unsuccessful if the regulations are not accepted by anglers or reduce angler participation in the fishery. To determine if harvest restrictions are successful overall, an evaluation of their effects on the fish population and the socioeconomic environment in which that fishery exists is necessary.

Analysis of the social effects of current and hypothetical harvest restrictions can provide managers with information about anglers' acceptance of current restrictions and direction for future management. Placing management decisions in the context of an economic decision-making process may make decisions concerning the resource more objective and may more accurately reflect the recreational value placed on that resource by its users. The objectives of this study were to examine the crappie fishery in Sardis Lake, Mississippi, and (1) assess angler acceptance of current and hypothetical harvest restrictions, (2) determine the recreational value of the fishery to anglers, (3) estimate possible changes in recreational value based on angler responses to hypothetical regulations, and (4) integrate results of our socioeconomic surveys with existing biological information.

\section{Study Area}

Sardis Lake is a flood control reservoir impounded in 1939 by the U.S. Army Corps of Engineers as part of the Yazoo River basin flood control project. The reservoir has a surface area of 23,675 ha at full pool. A $25.4-\mathrm{cm}$ length limit for crappies was established in 1989, and a creel limit of 30 crappies/d was established in 1992.

Sardis Lake occupies parts of Panola, Marshall, and Lafayette counties, Mississippi. Of a total population of 506,424 in the three-county region, 134,400 are anglers who fished 2,526,800 anglerdays in 1985 (USFWS 1988; USDC 1992a). The North Mississippi region (as described by Miranda and Frese 1989), which encompasses Sardis Lake, had the highest percentage of anglers who fished reservoirs and spillways below dams. The reservoir is a 1-h southerly drive from Memphis, Tennessee, (population 981,747, USDC 1992b). Roughly half of Sardis Lake anglers come from the Memphis area, a third from the surrounding counties, and the remainder from other Mississippi counties and states, particularly Missouri (K. O. Meals, unpublished).

\section{Methods}

Onsite interviews. - Socioeconomic and fishery data were collected from anglers during a roving creel survey conducted by personnel of the Mississippi Department of Wildlife Fisheries and Parks (MDWFP) in April-October 1995. In addition to collecting target species, catch, and effort information, crappie anglers surveyed were asked their county of origin, fishing trip expenditures, and distance traveled. Anglers targeting crappies were also asked questions identifying certain demographics that we used to classify the anglers into one of four crappie angler groupings: occasional, generalists, springtime, and specialists (as advanced by Allen and Miranda 1996). The crappie anglers were also provided with a postage-paid, mail-in survey seeking additional information (described in next section).

Mail-in survey.-The mail-in survey was designed to provide a profile of crappie anglers, to identify the level of angler understanding and satisfaction with existing regulations, and to obtain information to predict angler response to changes in the existing regulations. Questions included number of trips made by crappie anglers by season, scaled questions concerning satisfaction with current and hypothetical regulations, and anticipated change in fishing effort relative to hypothetical regulations. The data were summarized by mean, standard deviations, and percent response.

The demographic data collected from the creel survey were used to assess whether certain segments of the crappie angler population were more or less likely to participate in the mail-in survey than others. Each mail-in survey was assigned a number that was written on the creel card at the time of the interview, so the two were cross-referenced. Cross-referencing by number allowed for the subsequent nonresponse analysis, retained respondent anonymity, and prevented double-sampling of anglers for both the creel and mail surveys. Angler characteristics identified from the creel survey were analyzed to identify differences that might identify nonreporting biases associated with the mail-in survey. Bias associated with disproportionate returns of the mail-in questionnaire by angler segments was assessed with techniques originally described by Heckman (1979), and modified or described by Greene (1981), Hartman (1991), and Munn and Rucker (1994). The procedure treats the bias resulting from nonrandom 
samples as a model specification error (Heckman 1979). The first step was to estimate the probability of an angler participating in the mail-in survey. An angler's probability of participating was modeled as a function of the explanatory variables. This probability was estimated using logistic regression in which the explanatory variables considered were bank or boat angler (BKBT), artificial or live bait (BAIT), number of fish kept (NKPT), miles traveled (MILE), trip cost (TCST), use of specialized crappie poles (YPLS), race (RACE), use of depth finders (YDPTH), gender (GNDR), and whether fishing occurred primarily in the spring or year-round (FSEASON). The linear logistic model was

$$
\begin{aligned}
\operatorname{logit}(p) \\
=a+B_{1}(\mathrm{BKBT})+B_{2}(\mathrm{BAIT})+B_{3}(\mathrm{NKPT}) \\
+B_{4}(\mathrm{MILE})+B_{5}(\mathrm{TCST})+B_{6}(\mathrm{YPLS}) \\
+B_{7}(\mathrm{RACE})+B_{8}(\mathrm{YDPTH})+B_{9}(\mathrm{GNDR}) \\
+B_{10}(\mathrm{FSEASON})
\end{aligned}
$$

where $\operatorname{logit}(p)$ is the logistic probability of participation, $a$ is intercept estimate, and $B_{\mathrm{i}}$ is a parameter estimate.

Significance was determined by a $-2 \log$-likelihood chi-square at $\alpha=0.05$. If the chi-square value was not significant, we assumed there was no difference between respondents and nonrespondents and that no adjustment for disproportionate returns was needed. If bias was shown, Hartman's (1991) modification of step 2 of Heckman's (1979) procedure was necessary to determine whether response rates differed by angler characteristics.

Economic survey.-Recreational value (consumer surplus) of the fishery to individual crappie anglers was estimated using the travel-cost method (TCM). In the TCM, cost is a function of quantity of the product demanded, in this case, trips per year. Consumer surplus represents the maximum amount above actual expenditures that resource users are willing to pay to continue to fish, which was obtained by regressing travel cost on fishing effort (Weithman 1986; Talhelm et al. 1987; Freeman 1992).

Travel cost information, defined as expenditures per angler per trip, was collected during the onsite creel interviews. Out-of-pocket expenditures estimated by anglers included fuel, bait, ice, food, and lodging. In conjunction with distance traveled, opportunity-cost of traveling time (the wages that could have been earned during travel time) was estimated (Cole et al. 1986) with the wage set at US\$4.25 (1995 minimum wage) and average driving speed of $64 \mathrm{kph}$ (American Automobile Association 1990). The cost per trip to Sardis Lake (CPT) was calculated as follows:

$$
\mathrm{CPT}=\mathrm{TC}+\mathrm{EX},
$$

where EX is expenditures, and TC is the roundtrip travel cost or $\mathrm{TC}=\$ 4.25 / \mathrm{h} \times 2$ (mileage $/ 64$ $\mathrm{kph})$.

Because the relationship between cost and demand was nonlinear, nonlinear least-squares regression was used to estimate the individual angler cost function, as follows:

$$
C_{i}=B_{0} T T_{i}^{B_{1}}
$$

where $C_{i}$ is the $i$ th angler's mean cost per trip to Sardis Lake, $B_{0}$ is intercept parameter estimate, $B_{1}$ is slope parameter estimate, and $\mathrm{TT}_{i}$ is total trips for each angler per year.

The average cost per angler was computed as the mean number of trips to the site. Consumer surplus was estimated as the area under the estimated cost function but above the average cost. The area under the curve was determined by integrating the equation for the estimated cost function over the interval $0-C$, where $C$ is the mean number of trips. This area represents gross willingness to pay (Figure 1). To estimate consumer surplus per year the area of the polygon representing actual expenditures was computed and subtracted from gross willingness to pay. To estimate mean consumer surplus per angler per trip, the annual consumer surplus estimate was divided by the mean number of trips (Figure 1). Asymptotic $95 \%$ confidence interval (CI) estimates for the slope and intercept parameters were used to compute the $95 \% \mathrm{CI}$ around the estimate of mean consumer surplus (SAS Institute 1994).

Aggregate demand estimates.-Roving creel data using nonuniform probability sampling were used to estimate total trips per year made by crappie anglers based on methods for determining effort developed by Malvestuto et al. (1978) and Malvestuto (1996). Creel sampling had two components: angler counts and angler surveys (i.e., interviews). Counts were conducted systematically by boat. The lake was divided into five sections so counts and surveys could be conducted by boat within the 4-h creel period. Lake sections were selected randomly with a probability proportional 


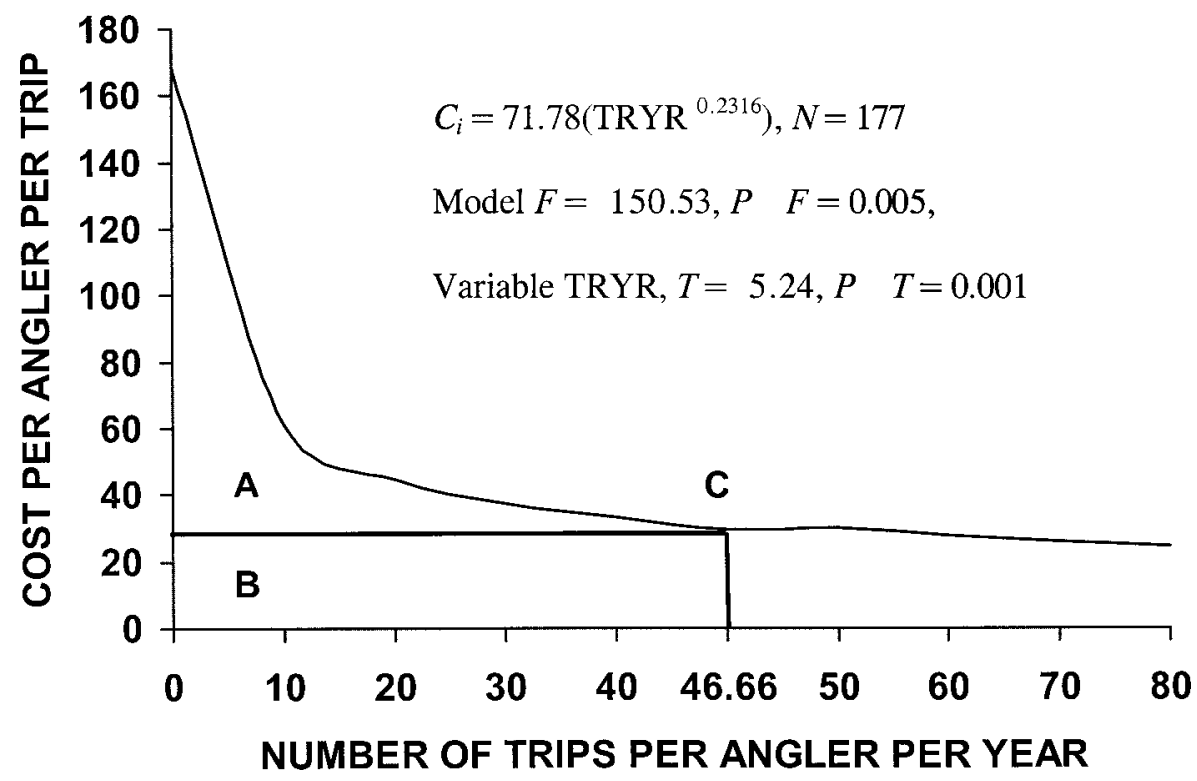

FIGURE 1.- Nonlinear regression model used to estimate the consumer surplus for crappie anglers in Sardis Lake, Mississippi, in 1995. Polygon A represents consumer surplus, polygon B current expenditures, and point C the mean number of trips per year per angler. Polygons A plus B equal gross willingness to pay. The response variable $C_{i}$ in the model is cost per angler per trip, the variable TRYR represents the trips per angler per year, and $N=$ sample size.

to the amount of fishing effort expected to occur within the sections.

Angler creel surveys were conducted within the randomly selected sections. The angler survey was divided into time blocks of 1 month and the blocks were divided into sampling units of $4 \mathrm{~h} / \mathrm{d}$. A sampling day contained three sampling units: AM (0600 to 1000 hours), noon (1000-1400 hours), and PM (1400-1800 hours). Times were shifted 1 $\mathrm{h}$ forward during daylight savings time. The proportional fishing effort was determined from overflight data for the years 1988-1990, provided by the MDWFP. Sampling units were stratified by weekend days or week days because fishing effort varied; 4 weekdays and 4 weekend days were sampled monthly. Each fish species sought by anglers were identified and coded. Additionally, anglers were asked to identify if there target species was crappie. Each crappie angler was counted as a crappie trip for the purposes of estimating aggregate demand. Data were expanded as described by Malvestuto et al. (1978), except that only the total number of anglers targeting crappies was determined for each monthly sampling period stratified by weekend and weekdays (i.e., we did not expand catch or effort). The total number of crappie anglers was determined by summing the number of anglers for each monthly sampling period.
Creel surveys were not done during the winter months (November-March). A winter estimate was obtained by using the breakdown of trips by season indicated in the mail-in survey. The proportion of the number of trips for the winter versus all seasons was calculated. This value was then used to derive the proportional number of trips that would have been taken during the winter, based on aggregate demand estimates obtained from the 7 months in which creel surveys were conducted.

The TCM estimate of economic value was extrapolated to the crappie fishery based on the estimate of total demand. This was done by multiplying the annual aggregate demand estimate by the TCM estimate of consumer surplus per crappie angler per trip and gross willingness to pay per crappie angler per trip.

Changes in aggregate demand were estimated from responses to hypothetical harvest regulations provided in the mail-in survey. Estimates were based on the percentage of crappie anglers who indicated they would quit fishing in response to different harvest restrictions, and by assuming a $5 \%$ increase or decrease in effort for anglers who responded by saying they would fish more or less, respectively. Aggregate consumer surplus was estimated from these changes in aggregate demand.

Changes in aggregate demand based solely on 
survey responses do not consider changes in intercept or slope parameter estimates of the TCM regression equation and ultimately, consumer surplus for individual anglers. Consequently, changes in intercept and slope estimates were tested. Equation (3) was linearized and a dummy variable (DMY) identifying the adjusted and unadjusted data was created to test for different intercepts (Affifi and Clark 1990). The interaction between the dummy variable and the unadjusted and adjusted trips (DMYXTRYR) was used to test for differences in slope estimates (Affifi and Clark 1990). The linearized regression equation was

$$
\begin{aligned}
\text { LNCOST }= & \text { LNTRYR }+ \text { DMY } \\
& + \text { DMYXTRYR; }
\end{aligned}
$$

$\mathrm{LNCOST}=\log _{e}$ of the $i$ th angler's cost per trip to Sardis Lake, LNTRYR $=\log _{e}$ of trips/angler/ year, $\mathrm{DMY}=$ a dummy regressor variable identifying adjusted and unadjusted demand estimates, and DMYXTRYR = the DMY and LNTRYR interaction variable that tests for differences in slope of the adjusted and unadjusted demand estimates.

If the estimated coefficient for either DMY or DMYXTRYR was significant $(\alpha=0.05)$, the new TCM equation (3) was then integrated to estimate a new consumer surplus value based on the adjusted data. This consumer surplus value was then extrapolated to the entire crappie fishery based on adjusted aggregate demand.

\section{Results}

\section{Nonresponse Bias}

The chi-square estimate of model fit indicated the nonresponse model did not explain a significant portion of the variability in response rates based on the variables considered $\left(\chi^{2}=11.99, P\right.$ $=0.29$; Table 1$)$. These results indicate the mailin survey respondents did not differ from nonrespondents and no adjustments for nonrespondents was necessary.

\section{Angler Mail-In Survey}

The Sardis Lake creel survey was conducted from April through October 1995. A total of 295 questionnaires were distributed, and 87 (30\%) were returned. Anglers averaged $19 \mathrm{~d}$ fishing in the spring $(N=76, \mathrm{SD}=17.5), 12 \mathrm{~d}$ in summer $(75,13.8), 13 \mathrm{~d}$ in the fall $(74,16.0)$, and $4 \mathrm{~d}$ in winter $(67,8.0)$.

Anglers were asked for their opinion of the current length and creel limits and response to hypothetical regulations. If they had fished the lake
TABLE 1.-Analysis of maximum likelihood estimates of survey response bias for creel and mail-in surveys conducted on Sardis Lake, Mississippi, 1995. The significance of all variables in explaining model fit was measured by -2 log-likelihood chi-square, and independent variables were tested by Wald chi-square at $P=0.05$. Sample size was 249 .

\begin{tabular}{lrc}
\hline \multicolumn{1}{c}{ Variable measured } & $\chi^{2}$ & $P$ \\
\hline All & 10.94 & 0.36 \\
Bank or boat angler & 0.41 & 0.52 \\
Type of bait used & 0.01 & 0.94 \\
Number of fish kept & 2.37 & 0.12 \\
Mileage & 0.14 & 0.71 \\
Travel cost & 0.07 & 0.79 \\
Use of specialized poles & 0.27 & 0.61 \\
Race & 0.19 & 0.66 \\
Use of depth finder & 3.60 & 0.06 \\
Gender & 0.73 & 0.39 \\
Fishing season & 1.37 & 0.24 \\
\hline
\end{tabular}

for more than 5 years, they were also asked what effect on their fishing the new harvest restrictions may have had. Twelve percent of the anglers surveyed had fished Sardis Lake for less than 5 years, $14 \%$ had fished the lake for 5-10 years, and 74\% had fished the lake for more than 10 years $(N=$ 85).

At least $90 \%$ of anglers were satisfied with present size and creel limits (Table 2). Although no large change in numbers of crappies caught was noted, over $60 \%$ of crappie anglers believed that average crappie size was larger, and over $70 \%$ believed crappie fishing would improve within 5 years.

Seventy-five percent of crappie anglers would fish less or quit fishing if the daily creel limit was reduced to 10 crappies/d, but almost $90 \%$ would not change their level of fishing effort, even if they could keep 40 or 50 crappies/d (Table 3). Anglers did not indicate they would change fishing effort if the length limit was less than $31 \mathrm{~cm}$, but $50 \%$ would fish less or quit fishing if the limit was 31 $\mathrm{cm}$.

\section{Economic Survey}

Due to the $30 \%$ response rate on mail-in surveys, information on the number of trips per year made by anglers was obtained from creel surveys. This change allowed all individual TCM data to be gathered during the onsite survey. Trip information from mail and creel surveys were combined for TCM analysis. The total combined sample size for the TCM analysis was 177 (67 mail surveys and 110 creel surveys).

The results of the nonlinear regression indicated 
TABLE 2.--Responses (\%) to questions about satisfaction with current harvest restrictions, changes in effort, and perceptions of the crappies fishery by anglers in Sardis Lake, Mississippi, 1995.

\begin{tabular}{|c|c|c|c|c|c|}
\hline $\begin{array}{l}\text { Number } \\
\text { of } \\
\text { responses }\end{array}$ & \multicolumn{5}{|c|}{ Percentages by response option to question } \\
\hline \multicolumn{6}{|c|}{ How satisfied are you with the current bag limit of 30 crappie/person/day? } \\
\hline 83 & Not satisfied $=2$ & Slightly satisfied $=6$ & Satisfied $=40$ & Very satisfiec & \\
\hline \multicolumn{6}{|c|}{ How satisfied are you with the crappie length limit of 10 inches? } \\
\hline 83 & Not satisfied $=6$ & Slightly satisfied $=4$ & Satisfied $=34$ & Very satisfiec & \\
\hline \multicolumn{6}{|c|}{ Have the new length and bag limit regulations on crappie caused you to fish more or less often on Sardis Lake? } \\
\hline 73 & Much less $=0$ & Less $=1$ & Same $=74$ & More $=23$ & Much more $=2$ \\
\hline \multicolumn{6}{|c|}{ Are you catching more or less crappies now than before the length and bag limits? } \\
\hline 73 & Much less $=4$ & Less $=12$ & Same $=52$ & More $=27$ & Much more $=4$ \\
\hline \multicolumn{6}{|c|}{ Are you catching bigger crappies now than before the length and bag limits? } \\
\hline 74 & Much smaller $=0$ & Smaller $=5$ & Same $=31$ & Bigger $=57$ & Much bigger $=7$ \\
\hline \multicolumn{6}{|c|}{ Do you think that 5 years from now crappie fishing will be better or worse because of the length and bag limits? } \\
\hline 79 & Much worse $=3$ & Worse $=4$ & Same $=19$ & Better $=51$ & Much better $=23$ \\
\hline
\end{tabular}

the independent variable, trips per year, explained a significant amount of variation in cost per trip $(T=-5.24, r=0.31, P=0.001)$. The slope of the regression indicated number of trips declined as cost increased (Figure 1). The mean number of annual trips was $46.66(\mathrm{SD}=47.69)$. Mean expenditure estimated from the TCM model was \$29.48/crappie-angler trip, and average consumer surplus per was $\$ 8.88 /$ trip (Figure 1). Consequently, based on the TCM, total willingness-to-pay for Sardis Lake crappie anglers was $\$ 38.36 /$ trip.

\section{Aggregate Demand}

There were 73,212 crappie fishing trips made from April to October 1995, and the proportional effort for the winter months was 2,389 trips. Of the total annual estimate of 75,601 trips, $73 \%$ occurred from April through June.

TABLE 3.- Survey responses (\%) to hypothetical creel and length limits, Sardis Lake, Mississippi, 1995.

\begin{tabular}{cccccc}
\hline & & \multicolumn{4}{c}{ Response percentage } \\
\cline { 3 - 6 } Limit & $\begin{array}{c}\text { Sample } \\
\text { size }\end{array}$ & $\begin{array}{c}\text { Fish } \\
\text { more }\end{array}$ & No change Fish less & $\begin{array}{c}\text { Quit } \\
\text { fishing }\end{array}$ \\
\hline Creel (number) & & & & & \\
0 & 70 & 2 & 16 & 11 & 71 \\
10 & 71 & 3 & 22 & 44 & 31 \\
20 & 74 & 5 & 62 & 30 & 3 \\
40 & 77 & 4 & 88 & 5 & 3 \\
50 & 73 & 3 & 88 & 7 & 2 \\
Length (in) & & & & & \\
None & 62 & 3 & 90 & 5 & 2 \\
8 & 67 & 4 & 90 & 6 & 0 \\
11 & 77 & 3 & 97 & 0 & 0 \\
12 & 69 & 1 & 48 & 44 & 7 \\
13 & 69 & 1 & 44 & 38 & 17 \\
\hline
\end{tabular}

Based on estimates of annual aggregate demand and angler total willingness-to-pay generated by the TCM, the annual gross willingness-to-pay (GWP) of the Sardis Lake crappie fishery was \$2.9 million in 1995. Based on the TCM estimate of average consumer surplus, consumer surplus (economic value after expenses) was $\$ 671,000$.

Effects of hypothetical harvest restrictions on the economic value of the Sardis Lake crappie fishery were estimated by altering aggregate demand derived from the mail-in survey. Three scenarios were analyzed: a creel limit of 10 crappies/d, a creel limit of 20 crappies/d, and a minimum length limit of $31 \mathrm{~cm}$. Analysis of possible changes in individual consumer surplus for each scenario indicated no significant differences in intercept and slope estimates. Therefore, the three estimates consumer surplus were not statistically different (Table 4), so changes in aggregate value were based on the unadjusted TCM consumer surplus and GWP estimates.

Under a creel limit of 20 crappies/d, 2,960 fewer trips could be expected resulting in an annual reduction in both consumer surplus and GWP of approximately $4 \%(\$ 26,300$ and $\$ 113,500$, respectively; Table 5). The net change in out-of-pocket expenses was about $7 \%(\$ 126,000)$. Under a creel limit of 10 crappies/d, about 24,986 fewer trips could be expected, resulting in an annual reduction in both consumer surplus and GWP of approximately $33 \%$ ( $\$ 222,000$ and $\$ 958,000$, respectively). The net change in out-of-pocket expenses was about $39 \%(\$ 655,000)$. Under the length limit of $31 \mathrm{~cm}, 7,035$ fewer trips could be expected, caus- 
TABLE 4.- - Linear regression comparison of crappie angler individual trip demand changes for travel-cost-method estimates of consumer surplus, based on responses of anglers to hypothetical creel and length limits for the crappie fishery. Data from creel surveys and mail-in surveys on Sardis Lake, Mississippi, 1995, were combined. The variable LNTRYR is the natural logarithm of trips per year; DMY is a dummy regressor variable identifying adjusted and unadjusted demand that tests for differences in intercepts between demand estimates; DMYXTR is the interaction between DMY1 and LNTRYR, which tests for differences in slope of the unadjusted and adjusted demand estimates; $t$ is Student's $t$-value.

\begin{tabular}{|c|c|c|c|c|c|c|}
\hline \multirow[b]{3}{*}{ Variable } & \multicolumn{4}{|c|}{ Creel limit } & & \\
\hline & \multicolumn{2}{|c|}{ 20/crappies/d } & \multicolumn{2}{|c|}{ 10/crappies/d } & \multicolumn{2}{|c|}{ Length limit of 12 in } \\
\hline & $t$ & $P$ & $t$ & $P$ & $t$ & $P$ \\
\hline Intercept & 13.42 & $<0.01$ & 13.04 & $<0.01$ & 12.93 & $<0.01$ \\
\hline LNTRYR & -3.77 & $<0.01$ & -3.67 & $<0.01$ & -3.66 & $<0.01$ \\
\hline DMY1 & 0.06 & 0.95 & -1.94 & 0.06 & -1.44 & 0.25 \\
\hline DMYXTR & -0.10 & 0.92 & 1.56 & 0.12 & 1.10 & 0.28 \\
\hline
\end{tabular}

ing an annual reduction in both consumer surplus and GWP of about $9 \%(\$ 61,900$ and $\$ 270,000$, respectively). The net change in out-of-pocket expenses, excluding lodging, was about $16 \%$ $(\$ 261,000)$.

\section{Conclusions}

\section{Angler Surveys}

Although the number of responses was lower than anticipated, we think survey results are still useful particularly with respect to magnitude and direction of change. Survey results indicated the majority of crappie anglers perceived the current harvest regulations to be satisfactory and believed the regulations have improved the fishery. Most crappie anglers experienced no change or an increase in effort in response to current length and creel limits compared with prior regulations. Reactions to hypothetical changes in either length or

TABLE 5.-Estimated increase $(+)$ or decrease $(-)$ in the annual number of trips and consumer surplus (rounded to the nearest 100) for crappie anglers, based on responses to hypothetical length and creel limits, Sardis Lake, Mississippi, 1995.

\begin{tabular}{cccc}
\hline Limit & $\begin{array}{c}\text { Change in annual } \\
\text { number of trips }\end{array}$ & $\begin{array}{c}\text { Percentage } \\
\text { change } \\
\text { in trips }\end{array}$ & $\begin{array}{c}\text { Change in } \\
\text { consumer } \\
\text { surplus (US\$) }\end{array}$ \\
\hline $\begin{array}{c}\text { Creel (number) } \\
0\end{array}$ & $-54,357$ & -71.9 & $-482,500$ \\
10 & $-24,986$ & -33.1 & $-222,000$ \\
20 & $-2,960$ & -3.9 & $-26,300$ \\
40 & $-2,041$ & -2.7 & $-18,000$ \\
50 & $-2,192$ & -2.9 & $-19,500$ \\
Length (in) & & & $-11,400$ \\
None & $-1,285$ & -1.7 & -500 \\
8 & -61 & -0.08 & +900 \\
11 & +98 & +0.1 & $-61,900$ \\
12 & $-7,035$ & -9.3 & $-128,800$ \\
13 & $-14,515$ & -19.2 & \\
\hline
\end{tabular}

creel limits were mixed, but in general a decrease in participation was predicted for any change in limits, regardless of whether they were made more liberal or more restrictive. Crappie anglers indicated a pronounced negative response to changes in creel limits below 20 crappies/d. Angler responses to hypothetical creel limits from our study are supported by Cook et al. (2001), who indicated that creel limits low enough to effectively limit harvest may be socially unacceptable. Conversely, anticipated reaction to changes in length limits were relatively modest, indicating length limits may gain acceptance with anglers over time.

A general resistance to change in harvest restrictions was apparent in this study, whether the restrictions were made more liberal or more restrictive. However, acceptance or rejection of hypothetical regulations over time is unknown. Based on anecdotal evidence, some resistance was registered before implementation of the current regulations, which now garner strong support. This suggests that regulations gain acceptance with time if they are perceived to produce tangible benefits, such as more or larger fish.

\section{Economics}

The TCM estimate of average consumer surplus of $\$ 8.88 /$ trip was within the range of results of other studies (AFS 1992). Palm and Malvestuto (1983) reported an average consumer surplus of $\$ 10.80 / d$ for crappie anglers on West Point Reservoir, Alabama. Cole at al. (1986) reported a value of $\$ 10.14 / \mathrm{d}$ for warmwater anglers fishing reservoirs on the Rio Grande River, New Mexico. Both of these studies used the TCM method for estimating consumer surplus.

Estimates of changes in consumer surplus and aggregate demand indicate the Sardis Lake crappie 
fishery would be significantly affected by reducing creel limits to a level that would affect crappie population structure ( $<15 /$ crappies/d, Mitzner 1984; $\leq 6$ crappies/d, Cook et al. 2001). Recreational value of the crappie fishery would be reduced by about a third for a creel limit of 10 crappie/d. However, changes in length limits are not likely to produce significant changes in angler demand and consumer surplus, unless the limits are $31 \mathrm{~cm}$ or greater.

The large reductions of crappie fishery value in reaction to changes in creel limits may be due to anglers use of creel limits as a measure of their success and angling skill (Noble and Jones 1993; Cook et al. 2001). The reduction in fishery value also highlights the disparity between anglers perceptions and biological evidence about the effectiveness of creel limits for enhancing fish population structure (Radomski et al. 2001).

The evidence of economic responses to changes in regulations support continuance of the crappie harvest restrictions in effect for Sardis Lake during our study. Our findings indicate that creel limit reductions would not be an acceptable management tool for the Sardis Lake crappie fishery. Reaction to length limits was not as pronounced and may be an option for managing the crappie fishery.

\section{Management Implications}

Biological information concerning the effect of current length limits on Sardis Lake is mixed. Miranda et al. (1996) found increased growth of age0 and age- 1 black crappies $P$. nigromaculatus and age- $0-2$ white crappies $P$. annularis following implementation of the $25 \mathrm{~cm}$ length limit. Miranda et al. (1996) suggested increased growth of these age-classes may have occurred because populations were not at carrying capacity and density dependent factors were not limiting growth rates of fish protected by the length limit.

Mitzner (1984) indicated that creel limits are ineffective in changing crappie population structure unless they are less than 15 crappies/d. Cook et al. (2001) suggest even more severe creel limits ( $\leq 6$ crappies/d) to effect changes in population structure of crappies in Minnesota lakes. This, combined with information provided by Miranda et al. (1996), suggests that the reduction in creel limits from 50 to 30 in 1992, probably had little effect on population characteristics of crappies in Sardis Lake.

Increased growth of black crappies and white crappies following implementation of the length limit and large fluctuations in recruitment suggest the limiting factor on the Sardis Lake crappie population may not be exploitation (Meals and Miranda 1991; Miranda et al. 1996). Population characteristics supported continuing the current length and creel limits for white crappies but did not for black crappies (Miranda et al. 1996). However, due to the difficulty in managing each species separately, continuance of current regulations for both species were recommended.

Options that were not explored in this study include slot limits, gear restrictions, and closed seasons. Evidence from Sardis Lake and other Mississippi lakes and reservoirs concerning size selectivity associated with crappie angling suggest that slot limits and season or gear restrictions may be effective in enhancing characteristics of crappie populations (Miranda and Dorr 2000). However, resistance to these regulations by crappie anglers is unknown. A preliminary survey exploring the possible response to such regulations would provide a baseline reference of support or opposition. Educating anglers about the importance of the regulations to the fishery could be beneficial in establishing acceptance of any proposed regulations.

Our data suggest more restrictive length limits as the most favorable tool for managing the Sardis Lake crappie fishery. Conversely, creel limits as a management tool may be approaching a point of diminishing returns. Potentially, large decreases in value of the crappie fishery to its users and potentially small gains in population structure of crappies may limit the management options associated with creel limits.

Enactment of more or less restrictive regulations in the Sardis Lake crappie fishery may not be beneficial to the crappie population or to anglers, unless exploitation increases substantially. Biological and socioeconomic information support continuing the current regulations on the Sardis Lake crappie fishery. However, acceptance of alternative restrictions, such as slot limits and gear or season restrictions, should be explored if exploitation is judged excessive.

\section{Acknowledgments}

Funding for this project was provided by the Mississippi Department of Wildlife, Fisheries, and Parks. We thank L.E. Miranda and D. Gill for their insights; P. Gerard, G. Weerakody and T. Wittig for their help with statistical aspects of this study; and E. Irwin, J. Jones, and three anonymous reviewers for helpful comments on earlier drafts of this manuscript. 


\section{References}

Affifi, A. A., and V. Clark. 1990. Computer-aided multivariate analysis. Van Nostrand Reinhold, New York.

AFS (American Fisheries Society). 1992. Investigation and valuation of fish kills. American Fisheries Society, Special Publication 24, Bethesda, Maryland.

Allen, M. S., and L. E. Miranda. 1996. A qualitative evaluation of specialization among crappie anglers. Pages 145-151 in L. E. Miranda and D. R. DeVries, editors. Multidimensional approaches to reservoir fisheries management. American Fisheries Society, Symposium 16, Bethesda, Maryland.

American Automobile Association. 1990. Your driving costs. American Automobile Association, Heathrow, Florida.

Cole, R., T. Ward, F. Ward, and R. Deitner. 1986. A simulation model for managing fisheries reservoirs on the Rio Grande of New Mexico. Pages 18-27 in G. E. Hall and M. J. Van Den Avyle, editors. Reservoir fisheries management: strategies for the 80's. American Fisheries Society, Southern Division, Reservoir Committee, Bethesda, Maryland.

Cook, M. F., T. J. Goeman, P. J. Radomski, J. A. Younk, and P. C. Jacobson. 2001. Creel limits in Minnesota: a proposal for change. Fisheries 26(5):19-26.

Freeman, M. A. 1992. The measurement of environmental and resource values. Resources for the Future, Washington, D.C.

Greene, W. H. 1981. Sample selection bias as a specification error: comment. Econometrica 49:795-798.

Hartman, R. S. 1991. A monte carlo analysis of alternative estimators in models involving selectivity. Journal of Business and Economic Statistics 9:4149.

Heckman, J. J. 1979. Sample selection bias as a specification error. Econometrica 47:153-161.

Malvestuto, S. P. 1996. Sampling the recreational creel. Pages 591-623 in B. R. Murphy and D. W. Willis, editors. Fisheries techniques, 2nd edition. American Fisheries Society, Bethesda, Maryland.

Malvestuto, S. P., W. D. Davies, and W. L. Shelton. 1978. An evaluation of the roving creel survey with nonuniform probability sampling. Transaction of the American Fisheries Society 107:255-262.

Meals, K. O., and L. E. Miranda. 1991. Variability in abundance of age- 0 centrarchids among littoral habitats of flood control reservoirs in Mississippi. North American Journal of Fisheries Management 11: 298-304.

Miranda, L. E., M. Allen, B. S. Dorr., and L. C. Isaak. 1996. Evaluation of regulations restrictive of crappie harvest. Mississippi Department of Wildlife, Fisheries and Parks, Freshwater Fisheries Report 152, Grant F-105, Jackson.

Miranda, L. E., and B. S. Dorr. 2000. Size selectivity of crappie angling. North American Journal of Fisheries Management 20:706-710.

Miranda, L. E., and W. Frese. 1989. Mississippi angler survey. Mississippi Department of Wildlife, Fisheries and Parks, Freshwater Fisheries Report 81, Jackson.

Mitzner, L. 1984. Crappie management: problems and solutions. North American Journal of Fisheries Management 4:339-340.

Munn, I. A., and R. R. Rucker. 1994. The value of information services a market for factors of production with multiple attributes: the role of consultants in private timber sales. Forest Science 40: 474-496.

Noble, R. L., and T. W. Jones. 1993. Managing fisheries with regulations. Pages 383-404 in C. C. Kohler and W. A. Hubert, editors. Inland fisheries management in North America. American Fisheries Society, Bethesda, Maryland.

Palm, R. C., Jr., and S. P. Malvestuto. 1983. Relationships between economic benefit and sport-fishing effort on West Point Reservoir, Alabama-Georgia. Transactions of the American Fisheries Society 112: 71-78.

Prochaska, F. J., and J. C. Cato. 1983. Economic considerations for fishery management. Pages 447-456 in L. A. Neilsen and D. L. Johnson, editors. Fisheries techniques. American Fisheries Society, Bethesda, Maryland.

Radomski, P. J., G. C. Grant, P. C. Jacobson, and M. F. Cook. 2001. Visions for recreational fishing regulations. Fisheries 26(5):7-18.

SAS Institute. 1994. SAS statistics user's guide. SAS Institute, Cary, North Carolina.

Talhelm, D. R., J. E. Hanna, and P. Victor. 1987. Product travel cost approach: estimating acid rain damage to sportfishing in Ontario. Transactions of the American Fisheries Society 116:420-431.

USDC (U.S. Department of Commerce). 1992a. 1990 census of population characteristics metropolitan areas, Mississippi. USDC, 1990 CP-1-26, Washington, D.C.

USDC (U.S. Department of Commerce). 1992b. 1990 census of population characteristics metropolitan areas. USDC, 1990 CP-1-1B, section 3 of 3, Washington, D.C.

USFWS (U.S. Fish and Wildlife Service). 1988. 1985 national survey of fishing, hunting, and wildlife associated recreation. USFWS, Washington D.C.

USFWS (U.S. Fish and Wildlife Service). 1996. 1996 national survey of fishing, hunting, and wildlife associated recreation. USFWS, Washington D.C.

Weithman, A. S. 1986. Measuring the value and benefits of reservoir fisheries programs. Pages 11-17 in G. E. Hall and M. J. Van Den Avyle, editors. Reservoir fisheries management: strategies for the 80's. American Fisheries Society, Southern Division, Reservoir Committee, Bethesda, Maryland.

Weithman, A. S. 1993. Socioeconomic benefits of fisheries. Pages 159-177 in C. C. Kohler and W. A. Hubert, editors. Inland fisheries management in North America. American Fisheries Society, Bethesda, Maryland. 